ENTREPRENEURSHIP AND SUSTAINABILITY ISSUES

ISSN 2345-0282 (online) http://jssidoi.org/jesi/ 2020 Volume 8 Number 1 (September)

http://doi.org/10.9770/jesi.2020.8.1(39)

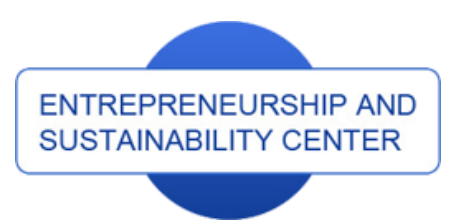

Publisher

http://jssidoi.org/esc/home

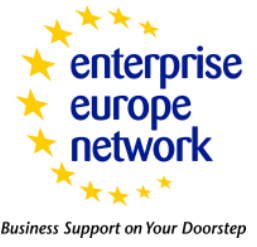

\title{
THE ASSOCIATION OF ENTREPRENEURIAL EDUCATION AND SUPPORT WITH ENTREPRENEURIAL INTENTION AT NORTHERN BOARDER UNIVERSITY: THE CASE OF STUDENTS FROM COLLEGE OF BUSINESS ADMINISTRATION
}

\author{
Waddah Omer ${ }^{1}$, Khaled Aljaaidi ${ }^{2}$ \\ ${ }^{1}$ Department of Accounting, College of Business Administration, Northern Border University, Saudi Arabia \\ ${ }^{2}$ Accounting Department, College of Business Administration, Prince Sattam bin Abdulaziz University, Saudi Arabia \\ E-mails: ${ }^{1}$ waddahkam@yahoo.com ; k.aljaaidi@psau.edu.sa ${ }^{2}$
}

Received 15 March 2020; accepted 25 June 2020; published 30 September 2020

\begin{abstract}
This study aims at empirically examining the association of entrepreneurial education and support with entrepreneurial intention among students in College of Business Administration at the Northern Boarder University for the academic year 2019-2020. Using data from a self-administered survey with a final sample of 266 students, the simple regression result indicates to a significantly positive association of the entrepreneurial education and support with entrepreneurial intention among College of Business Administration's students at Northern Boarder University. The results of this study should be useful to policy makers in Saudi Arabia at the country, ministry of education, the College of Business Administration, Northern Boarder University and elsewhere, as the KSA is aiming at achieving the ambitious KSA 2030 Vision.
\end{abstract}

Keywords: Entrepreneurial education and support; entrepreneurial intention; students from College of Business Administration; Northern Boarder University

Reference to this paper should be made as follows: Omer, W., Aljaaidi, K. (2020). The association of entrepreneurial education and support with entrepreneurial intention at Northern Boarder University: The case of students from College of Business Administration. Entrepreneurship and Sustaibability Issues, 8(1), 555-572. http://doi.org/10.9770/jesi.2020.8.1(39)

JEL Classifications: L26, L31, I25 


\section{ENTREPRENEURSHIP AND SUSTAINABILITY ISSUES}

ISSN 2345-0282 (online) http://jssidoi.org/jesi/

2020 Volume 8 Number 1 (September)

http://doi.org/10.9770/jesi.2020.8.1(39)

\section{Introduction}

Much evidence has demonstrated that there is a significant positive correlation between entrepreneurship and economic growth (Navarro, et al., 2009; Abdieva et al. 2019; Chienwattanasook \& Jermsittiparsert, 2019; Otache 2019a; Lopes et al., 2020; Velilla \& Ortega, 2020; Mukwarami et al., 2020). Entrepreneurship is regarded as one of the key elements to economic success, making a significant contribution to resolving unemployment problems, critically important at a time when a number of countries, both developed and emerging, are facing difficulties with graduate unemployment (Ahmad \& Xavier, 2012; Ndofirepi, 2016; Farrukh et al., 2019). Sternberg and Wennekers (2005) and Ferrandiz et al. (2018) specifically state that economic growth is extremely dependent upon effective innovators and large numbers of entrepreneurs.

Schulte (2004), Vicens and Grullón (2011), Wells (2014), Saji and Nair (2018), Kim and Park (2018), Che Embi et al. (2019), Bazan et al. (2020), and Lopes et al. (2020) all agree that universities, both now and in the future, have an important part to play in encouraging entrepreneurs by providing the students with the requisite skillsets to join their ranks. It is agreed that universities are at the center of critical thinking, leadership, creativity, and innovation, and through producing graduates with these qualities they have a direct influence on society as a whole. It is crucial that students have educational experiences that allow them to exercise informed decisionmaking in the real world. Matlay and Carey (2006) and Teixeira et al. (2018) state that in contemporary developing and developed nations the concept that entrepreneurship education can help save a stagnating or declining economy has become extremely popular. Research by Charney and Libecap (2000) demonstrated that emergent companies with entrepreneurship graduates either as owners or employees experienced 500\% more employment growth and sales than companies where entrepreneurship graduates were not present. Additionally, Arrif et al. (2010) state that entrepreneurship education, and entrepreneurship as a whole, is one of the most effective ways of solving problems of graduate unemployment. Matlay (2006) states that entrepreneurship education always correlates to both the amount and standard of entrepreneurial activity being enhanced.

A wide-ranging report produced after the UNESCO World Conference, 1998, laid great stress on how important entrepreneurship education is and demanded that national economies should think about how they could develop entrepreneurial skills (Greene et al., 2015). Entrepreneurship education encourages multifaceted thinking, allowing individuals to recognize where new opportunity exists and to convert concepts into reality. Kuratko (2004, quoted in Fitriati and Hermiati (2011)) regards entrepreneurship education as "a dynamic and social process in which a person, both as individual and in a collective group, identifies opportunities for innovation and action by transforming ideas into practices and activities with well-defined targets within social, cultural and economic contexts" (Luc, 2018). Entrepreneurship education has also been proposed as the optimal means of transferring the expanding number of graduates from education into the world of work, either salaried or selfemployed (Matlay \& Westhead, 2005; Alessa 2019; Che Embi et al., 2019).

This transfer is facilitated by entrepreneurial education by producing graduates who are more confident in their entrepreneurial skills and with taking risks (e.g., Otache 2019a;2019b). Promoting entrepreneurship in tertiary education is a way of increasing self-employment, risk-taking, and confident entrepreneurs (Segal et al., 2005). Richardson and Hynes (2008) states that entrepreneurship education in a broad application of the term offers crucial benefits. Wilson (2008) and others have stated that innovation and entrepreneurship must be thoroughly embedded in the curriculum to encourage students to adopt entrepreneurial ways of thinking. Essentially, entrepreneurial education is important as it promotes entrepreneurship (Barba-Sánchez \& Atienza-Sahuquillo, 2018), and this is beneficial to the individual, companies, and wider society (Alberti et al., 2004; Arias et al., 2018). 


\section{ENTREPRENEURSHIP AND SUSTAINABILITY ISSUES}

ISSN 2345-0282 (online) http://jssidoi.org/jesi/ 2020 Volume 8 Number 1 (September) http://doi.org/10.9770/jesi.2020.8.1(39)

Saudi Arabia is the largest economy in the Middle East (World Bank, 2019) and the world's 18th largest economy, with plans to be ranked higher by 2030 in line with the KSA 2030 Vision; the promotion of entrepreneurship is central to this. Saudi Arabia wants to gradually wean itself off depending on oil and creating a more diversified economy rooted in services like tourism, recreation, infrastructure, education, and health. Targets encompass boosting non-petroleum trading with other countries in consumer goods, boosting investment, and increasing government spend on the Armed Forces and equipment. A crucial element of KSA Vision 2030 is the reduction of unemployment. Because of this, Saudi universities, particularly business schools, have acknowledged that they must increase the promotion and teaching of entrepreneurship, and many entrepreneurship centers have been created for this reason, Northern Border University's amongst them.

The Entrepreneurship Center was established in 2018 to offer consultancy, feasibility studies, and project support for entrepreneurs, facilitating financing for startups and innovators. A course in entrepreneurship is now available in every academic department of the College of Business Administration as an elective. The purpose of these initiatives is to provide entrepreneurship education that will create sustainable businesses. Entrepreneurial intentions have been shown to be one of the most significant predictors for entrepreneurial behaviors (e.g., Gelaidan \& Abdullateef, 2017; Che Embi et al., 2019; Otache 2019a; 2019b; Otache et al., 2020; Thomassen et al. 2020). Gelard and Saleh (2011) states that the entrepreneurial intention of students must be carefully considered. While much research has been undertaken regarding entrepreneurship education, research regarding its influence is both limited and varied in its findings; indeed, there is little understanding about this area. The majority of research that has been undertaken as being in a variety of developing and developed nations, but not Saudi Arabia. Because of this, this research will assess the correlations between entrepreneurial education/support and entrepreneurial intention for students enrolled in the College of Business Administration at Northern Border University in the academic year 2019-2020.

This research adds to the knowledge base through assessing what promotes entrepreneurial intentions amongst students in Saudi Arabia in a specific State University, Northern Border University. The outcomes of this research will be of value to the academic community as there is little formal research looking at entrepreneurship in Saudi Arabia's universities. This research will provide a significant amount of data regarding entrepreneurship in Saudi Arabia's universities and make future predictions. As well as adding to the research regarding entrepreneurship, this research aims to inspire future researchers to investigate same subject. This research will offer practical direction that will be of assistance to both the University and the Ministry of Education, in that the results will help to inform University plans for enhancing the entrepreneurship intention of students regarding the achievement of KSA 2030 Vision both by improving the contemporary opportunities on offer and also by offering solutions to a number of challenges that exist for entrepreneurship within Saudi Arabia. Some challenges for the 2030 Vision program are to boost the proportion of GDP contributed by small and medium-sized enterprises (SMEs), to bring higher education and employment market closer together by helping students make better career choices, and to develop the talents of young people, making investments in their productivity in ways that will benefit them and society and the economy as a whole by, for example, decreasing unemployment.

This paper is organized as follwos. Section 2 reviews the literature and hypothesis development, section 3 discusses the research methodolody, section 4 highlights the results and discussions, and the final section introduces the conclusions and implications. 


\section{ENTREPRENEURSHIP AND SUSTAINABILITY ISSUES}

ISSN 2345-0282 (online) http://jssidoi.org/jesi/

2020 Volume 8 Number 1 (September)

http://doi.org/10.9770/jesi.2020.8.1(39)

\section{Literature review and hypothesis development}

Schulte (2004), Vicens and Grullón (2011), Wells' (2014) Saji and Nair (2018), Kim and Park (2018), Che Embi et al. (2019), Bazan et al. (2020), and Lopes et al. (2020) state that universities play a key part in encouraging entrepreneurship by providing students with the requisite skill set. All these researchers are in agreement that universities are central to critical thought, leadership, creativity, and innovation, and that the top graduates they produce have an influence on society as a whole. This makes it crucial that students are properly educated so that they can make the correct decisions in the future. Promoting and developing entrepreneurship/entrepreneurship education is a very "hot topic" in education in the majority of nations both as a social and political question (Ruskovaara \& Pihkala, 2013; Hoppe et al., 2017; Teixeira et al., 2018). Entrepreneurship education is regarded as central to encouraging the development of future entrepreneurs (Shamsudin et al., 2016) which in turn is essential for addressing many modern social, economic, and political problems (Gibb, 2002; Henry et al., 2005; Fulgence, 2015; Che Embi et al., 2019; Thomassen et al. 2020; Otache et al., 2020), which makes it an important topic for students from every discipline. Many contend that student perceptions of entrepreneurship are being changed due to college courses in entrepreneurship that give credit towards qualifications.

Entrepreneurship has spread from business schools into other academic programs. Recently entrepreneurial programs/courses have appeared in other areas of the curriculum, e.g., business studies (Parcell and Sykuta, 2005; Miller, 2007; Curry, 2012). Matlay and Carey (2006) and Teixeira et al (2018) both state that in the current era entrepreneurship education is regarded in both developing and developed countries as being a crucial way of resolving economic stagnation and decline. Charney and Libecap (2000) state that new companies that either employ or are owned by entrepreneurship graduates enjoy sales and employment expansionthat is five times higher than comparable firms without entrepreneurship graduates. Additionally, Ariff et al (2010) state that entrepreneurship, especially entrepreneurship education, is one of the best ways of moving a larger quantity of graduates into employment.

Matlay (2006) states that entrepreneurship education invariably leads to enhancements in both amounts and levels of excellence for entrepreneurial activities. A thorough report prepared after the UNESCO World Conference in 1998 emphasized how important entrepreneurship education is and demanded that national economies should promote developing entrepreneurial skills (Greene et al., 2015). Entrepreneurship education encourages multifaceted ways of thinking, allowing entrepreneurs to recognize novel opportunities and implement their ideas in practical ways. Kuratko (2004) (quoted in Fitriati and Hermiati (2011)) states that entrepreneurship education is "a dynamic and social process in which a person, both as individual and in a collective group, identifies opportunities for innovation and action by transforming ideas into practices and activities with well-defined targets within social, cultural and economic contexts." Entrepreneurship education has also been recognized as the best way of finding sufficient employment/self-employment for the needs of the expanding graduate population (Matlay \& Westhead, 2005; Alessa 2019; Che Embi et al., 2019; Bazan et al., 2020).

Entrepreneurship education helps this move to employment through promoting entrepreneurial confidence and making graduates more open to taking risks (e.g., Otache, 2019a, 2019b). Encouraging entrepreneurship in higher education is seen as a likely way of boosting entrepreneurial confidence, risk-taking behavior, and promoting self employment (Segal et al., 2005). Richardson and Hynes (2008) state that there are many advantages in the wider interpretation of entrepreneurship education across the curriculum. Agreeing, researchers like Wilson (2008) state that innovation and entrepreneurship must be thoroughly integrated to the curriculum to develop entrepreneurial enthusiasm and skills among students. Essentially, entrepreneurial education is important as a promoter of entrepreneurship (Barba-Sánchez \& Atienza-Sahuquillo, 2018), and this has a positive influence for the individual, business, and wider society (Alberti et al., 2004; Arias et al., 2018). 


\section{ENTREPRENEURSHIP AND SUSTAINABILITY ISSUES}

ISSN 2345-0282 (online) http://jssidoi.org/jesi/

2020 Volume 8 Number 1 (September)

http://doi.org/10.9770/jesi.2020.8.1(39)

The part played by entrepreneurship education in fostering entrepreneurial behaviors has attracted increased academic attention in recent years (Bae et al., 2014; Fayolle \& Gailly 2015; Martin et al., 2013; Entrialgo \& Iglesias, 2016; Che Embi et al., 2019; Otache 2019a; 2019b). This is unsurprising because a central aim of entrepreneurship education is the generation of positivity regarding entrepreneurship and to develop thinking skills (Fayole et al, 2002), assisting students in recognizing, screening, and perceiving opportunity, a central part of entrepreneurship (Busenitz et al., 2014). Learning about entrepreneurship encompasses conceptualizing, creativity, making choices, and problem-solving (e.g., Anne \& Liisa, 2011; Luc, 2018; Che Embi et al., 2019; Thomassen et al. 2020; Otache et al., 2020).

Entrepreneurship education means creating an environment for students that encourages entrepreneurship, which includes designing curricula satisfies the students' needs for entrepreneurship training. The more entrepreneurship education students are exposed to, the keener they will become on entrepreneurship (Ooi et al., 2011). In order to boost entrepreneurship, students should be offered programs/curricula that are relevant to this area (Shamsudin et al., 2017; Alessa 2019). Designing a relevant curriculum covering every area of entrepreneurship is a significant challenge for academia and specifically for universities (Fayoille et al, 2007). Thus, the following hypothesis is developed to be tested by this study:

\section{$H_{1}$ : Entrepreneurial education and support are related to the entrepreneurial intention.}

\section{Research methodoldoy}

\subsection{Questionnaire design}

This study uses the quantitative method as the most popular and useful format of conducting a field or survey research. The collection of the data using the questionnaire survey is an appropriate data collection instrument to answer the identified research questions: "To what extent does the entrepreneurial education and support are associated with the entrepreneurial intention among College of Business Administration students at Northern Boarder University?" The model of this study is adopted and adapted from several previous studies to fit in the Saudi Arabian setting (Aneizi, 2009; Luthje \& Franke, 2003; Ajzen, 2002; Nabi \& Holden, 2008; Kolvereid 1996; Scholten, et al., 2004; Fayolle, et al., 2006; Kolvereid, 1996). The level of entrepreneurial education and support is, empirically, tested with the level of entrepreneurial intention in order to identify the extent to which the entrepreneurial education impacts the degree of the entrepreneurial intention. The dependent variable for the model is the entrepreneurial education and support and the independent variable is the entrepreneurial intention. The questionnaire was distributed out in Arabic language to the sample of the study after conducting a translation from English. A survey is chosen because it involves surveying students and recording their responses for analysis.

The strength of the survey as a primary data collecting approach is that it does not require a visual or other objective perception of the information sought (Cohen, 1992). The questionnaire is divided into two section. Section A is designed to obtain demographic information of the respondents. Questions were asked in this part relate to gender, age, specialization and level of study. Section B of the questionnaire consisted of two parts. The first part measures the student intention to become an entrepreneur in the future. The second part measures the extent to which the university education and support are a good preparation for entrepreneurship. 


\section{ENTREPRENEURSHIP AND SUSTAINABILITY ISSUES}

ISSN 2345-0282 (online) http://jssidoi.org/jesi/

2020 Volume 8 Number 1 (September)

http://doi.org/10.9770/jesi.2020.8.1(39)

\subsection{Instrument of measurement}

\subsubsection{Demographic information}

Section A in the questionnaire includes demographic information of the respondents. The demographic variables included in the survey are: gender, specialization, study level and age. In terms of the gender variable, a nominal value of 1 is assigned to "male," and 2 is assigned to "female." With respect to specialization, a nominal value of 1 is assigned to "accounting," 2 is assigned to "law," 3 is assigned to "human resource," 4 is assigned to "finance" and 5 is assigned to "marketing." As for the study level, a nominal value of 1 is assigned to "first level," 2 is assigned to "second level," 3 is assigned to "third level," and 4 is assigned to "forth level." In terms of the age, a continuous value is assigned to the variable's measurement.

\subsubsection{Entrepreneurial Intention and entrepreneurial Education and Support}

Entrepreneurial intention is one of the concerns of this study. This variable is a 1-item that is measured using a four-point Likert Scale and is used to measure the extent of the students' intention towards entrepreneurship. The four-point Likert Scale is ranging from 1 (very improbable), indicating to the lowest entrepreneurial intention, to 4 (very probable), indicating to the highest entrepreneurial intention. In specific, the four-point Likert Scale and the measured data have been transformed into four categories: "1" (very improbable) indicates to the very low entrepreneurial intention, "2" (quite improbable) indicates to a low entrepreneurial intention, "3" (quite probable) indicates to a high entrepreneurial intention, and "4" (very probable) indicates to a very high entrepreneurial intention. The one specific entrepreneurial intention item used to measure the respondents' level of agreement towards their inclination to start with an entrepreneurial project in the future is "I plan to become self-employed in the foreseeable future after graduation." If a significant level of the given item "entrepreneurship" is at 0.05 or low, it is considered a significant relationship, otherwise it is not.

The variable "entrepreneurial education and support" consists of 8 -items to measure the extent to which the "entrepreneurial education and support" prepare the students to the entrepreneurship. A three-point Likert Scale is used to measure the level of agreement towards whether the university activities are deemed a good preparation for entrepreneurship. The Likert Scale is ranging from 1 (very accurate), indicating the highest agreement towards the contribution of the "entrepreneurial education and support" in preparing the students for the entrepreneurship, to 3 (not at all accurate), indicating the lowest agreement towards the contribution of the university activities in preparing students for the entrepreneurship.

In specific, the three-point Likert Scale and the measured data have been transformed into three categories: "1" (very accurate) indicates to a high level of agreement towards the contribution of the "entrepreneurial education and support" in preparing students for the entrepreneurship, "2" (somewhat accurate) indicates to the moderate level of agreement towards the contribution of the "entrepreneurial education and support" in preparing the students for the entrepreneurship, and " 3 " (not at all accurate) indicates to a low level of agreement towards the contribution of the "entrepreneurial education and support" in preparing the students for the entrepreneurship. However, this variable is subjected to reliability test before it was used for further analysis. There are eight specific "entrepreneurial education and support" items used to measure the respondents' level of agreement towards whether the "entrepreneurial education and support" are considered a good preparation for entrepreneurship. Statements in the questionnaire include:

- My university's creative atmosphere encourages the development of new business ideas.

- The University's curriculum encourages the leadership/social skills entrepreneurs require.

- The University's curriculum teaches students how to set up new companies.

- The University is supportive of creating multidisciplinary groups among students. 
- The University helps students to contact venture capitalists.

- The University plays an active part in promoting creating new companies.

- My university education will help me be an independent entrepreneur.

- My university education has encouraged me to consider taking risks.

If the significance level for particular items and for the whole "entrepreneurial education and support" category is 0.05 or lower, this is regarded as a significant correlation.

\subsection{Model specification and analysis}

This study applies a Simple Regression (SR) model. Nominal and continuous values were assigned to measure the value of the independent variables. In particular, the Model can be expressed as

follows:

$\mathrm{SR}(\mathrm{Y})=\beta 0+\beta 1 \mathrm{X} 1+\mathrm{e}$

Where the dependent variable is:

SR $(\mathrm{Y})=$ entrepreneurial intention (significance at level 0.05).

Where the independent variables are:

$\mathrm{X} 1=$ entrepreneurial education and support

e $\quad=$ Error term.

The analysis of data was completed using the SPSS version 20 for Windows. A descriptive statistical analysis using frequencies and percentages were used to describe the demographic variables. The research question was addressed using a simple regression.

\subsection{Data collection}

As for the sample to be selected for distributing out the questionnaire, the simple random sampling is applied to select sample subjects that represent the most suitable ones in providing data about the dimensions of the study. This technique is used in order to select the right sample to represent the whole population. Google Forms are used to design an electronic survey that is easily to be distributed out to a large number of the students. The electronic survey's link is then given to the students and faculty members in College of Business Administration to distribute it out to as many student as they could. The students were given a period of two weeks to return back a filled in survey. This technique resulted in a sample of 1400 selected students to obtain data from. These students are the most suitable respondents to provide data about the dimensions of the study. The sample subjects include students specialized in accounting, finance, marketing, human resource and law in College of Business Administration at Northern Boarder University for the academic year 2019-2020. The questionnaires returned were 326 questionnaires that represent $23 \%$ response rate from which 266 questionnaires were valid for analysis as shown in Table 3.1. 
Table 1. Sample selection

\begin{tabular}{|l|c|c|c|}
\hline \multicolumn{1}{|c|}{ Male section } & \multicolumn{1}{c|}{ Female section } & Totals \\
\hline Department of Law & 271 & 170 & 441 \\
\hline Department of Accounting & 85 & 164 & 249 \\
\hline Department of Human Resource Management & 206 & 299 & 505 \\
\hline Department of Finance & 39 & 102 & 141 \\
\hline Department of Marketing & 26 & 38 & 64 \\
\hline Totals & 627 & 773 & 1400 \\
\hline Returned respondents & 151 & 175 & 326 \\
\hline Invalid surveys & $(24)$ & $(36)$ & $(60)$ \\
\hline Final sample & 127 & 139 & 266 \\
\hline
\end{tabular}

In the goals of this research, we considered such procedural elements as disclosure restrictions, data entry, and incomplete questionnaires. Every effort was made to complete incomplete questionnaires, but participants were not pressurized into providing data. Around $6 \%$ of the surveys had to be rejected due to not being properly filled; complete sections were left unfilled or a number of statements were not answered, rendering the surveys invalid.

\section{Results and Discussions}

\subsection{Descriptive statistics}

\subsubsection{Profile of the respondents}

A total of 266 questionnaires were gathered from the survey. As shown in Table 2, the majority of the respondents $(52.3 \%)$ were male, and $(47.7 \%)$ were female.

Table 2. Profile of respondents

\begin{tabular}{|c|c|c|c|c|}
\hline Demographic information & & $\begin{array}{l}\text { quency } \\
=266)\end{array}$ & \multicolumn{2}{|c|}{ Percent $\%$} \\
\hline \multicolumn{5}{|l|}{ Panel A: Nominal variables } \\
\hline \multicolumn{5}{|l|}{ Gender } \\
\hline Male & & 127 & \multicolumn{2}{|c|}{47.7} \\
\hline Female & & 139 & \multicolumn{2}{|c|}{52.3} \\
\hline \multicolumn{5}{|l|}{ Specialization } \\
\hline Accounting & & 105 & \multicolumn{2}{|c|}{39.5} \\
\hline Law & & 121 & \multicolumn{2}{|c|}{45.5} \\
\hline Human resource & & 27 & \multicolumn{2}{|c|}{10.2} \\
\hline Finance & & 12 & \multicolumn{2}{|c|}{4.5} \\
\hline Marketing & & 1 & \multicolumn{2}{|c|}{0.4} \\
\hline \multicolumn{5}{|l|}{ Study level } \\
\hline First level & & 10 & \multicolumn{2}{|c|}{3.8} \\
\hline Second level & & 7 & \multicolumn{2}{|c|}{2.6} \\
\hline Third level & & 43 & \multicolumn{2}{|c|}{16.2} \\
\hline Fourth level & & 206 & \multicolumn{2}{|c|}{77.4} \\
\hline \multicolumn{5}{|c|}{ Panel B: Continuous variable } \\
\hline & Mean & Minimum & Maximum & St.Devation \\
\hline Age & 22 & 19 & 39 & 14.142 \\
\hline
\end{tabular}




\subsubsection{Entrepreneurial intention}

The students were asked whether they plan to become self-employed in the foreseeable future after graduation. Almost all the respondents indicate that they will "probable" (50\%) or "very probably" (46.6\%) become an entrepreneur some day in the near future. On the other hand, only (3\%), "improbable," and (0.4\%), "very improbable," are not thinking up to be entrepreneurs in the future as depicted in Table 3.

Table 3. Entrepreneurial intention (I plan to become self-employed in the foreseeable future after graduation)

\begin{tabular}{|l|c|c|}
\hline \multicolumn{1}{|c|}{ Scale } & $\begin{array}{c}\text { Frequency } \\
(\mathrm{n}=266)\end{array}$ & Percent \% \\
\hline Very probable & 124 & 46.6 \\
\hline Probable & 133 & 50 \\
\hline Improbable & 8 & 3 \\
\hline Very improbable & 1 & 0.4 \\
\hline Total & 266 & 100 \\
\hline
\end{tabular}

As shown by Table 3 that the students in College of Business Administration at Northern Boarder University have a high level of intention to be future businesspersons. This high degree of inclination gives a positive signal that the consequences on the economic growth would be great and positive (Sternberg \& Wennekers, 2005; Navarro et al., 2009; Acs \& Szerb, 2007; Audretsch \& Thurik, 2001; Marchesnay, 2011; Kasseeah. 2016; Ahmad \& Xavier, 2012). In addition, this entrepreneurial motivation would be the most powerful economic force in a manner that it contributes significantly to the unemployment problem (Ndofirepi, 2016; Ahmad \& Xavier, 2012).

\subsubsection{Entrepreneurial Education and Support}

Respondents were asked to rate different items of entrepreneurial education and support they might find in the university as presented by Table 4 .

Table 4. Entrepreneurial education and support

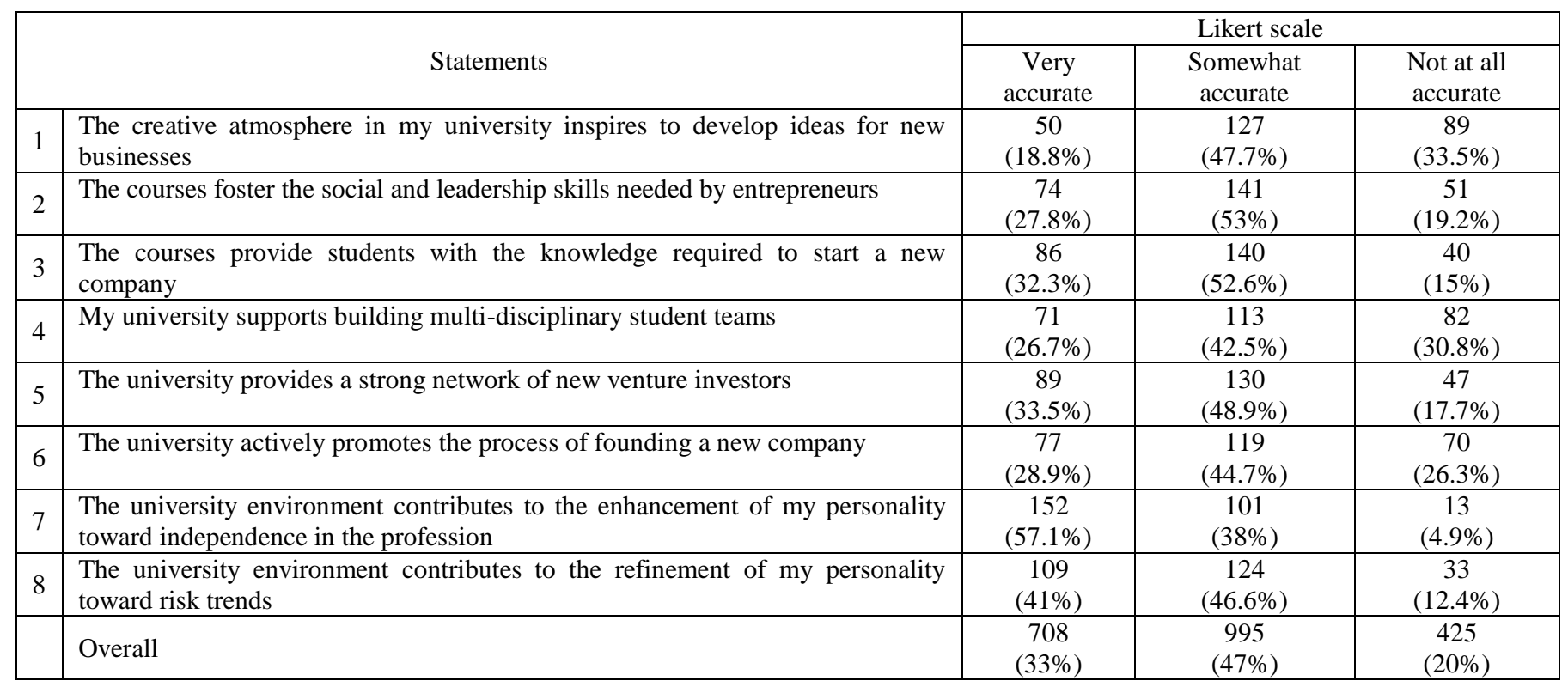




\section{ENTREPRENEURSHIP AND SUSTAINABILITY ISSUES}

ISSN 2345-0282 (online) http://jssidoi.org/jesi/ 2020 Volume 8 Number 1 (September) http://doi.org/10.9770/jesi.2020.8.1(39)

The percentage ratings of the "entrepreneurial education and support" of the respondents are measured using the three-point rating-scale. The "very accurate" rate indicates to a high agreement level to the item, the "somewhat accurate" refers to a moderate agreement level, and the "not at all accurate" indicates to a low agreement level. As for the first statement "the creative atmosphere in my university inspires to develop ideas for new businesses," the majority of the respondents indicate to a moderate agreement level (47.7\%) to a low agreement level (33.5\%). With regard to the second statement "the courses foster the social and leadership skills needed by entrepreneurs," the large portion of the respondents are moderately agreed (53\%) with the statement to a high degree agreement $(27.8 \%)$. Owning to the third statement "the courses provide students with the knowledge required to start a new company," the majority of the respondents are moderately agreed (52.6\%) with the statement to a high degree agreement (32.3\%).

In terms of the fourth statement "my university supports building multi-disciplinary student teams," the majority of the respondents indicate to a moderate agreement level (42.5\%) to a low agreement level (26.7\%). Regarding the fifth statement "the university provides a strong network of new venture investors," the higher portion of the respondents are moderately agreed $(48.9 \%)$ with the statement to a high degree agreement (33.5\%). In terms of the sixth statement "the university actively promotes the process of founding a new company," the majority of the respondents are moderately agreed (44.7\%) with the statement to a high degree agreement (28.9\%). As for the seventh statement "the university environment contributes to the enhancement of my personality toward independence in the profession," the majority of the respondents indicated to a high level of agreement (57.1\%) to a moderate level of agreement (38\%). Owing to the statement "the university environment contributes to the refinement of my personality toward risk trends," the highest portion of the respondents are moderately agreed $(46.6 \%)$ with the statement to a high degree agreement (41\%). Overall, the students are moderately (47\%) to highly (33\%) agreed that the entrepreneurial education and support at the Northern Boarder University enhance their entrepreneurial intention.

Table 5 ranks the items of the entrepreneurial education and support from the highest to the lowest. The range is between $95.1 \%$ to $66.5 \%$ indicating that the university entrepreneurial education and support enhance the students' entrepreneurial intention. Table 5 ranks the percentages for the 8 statements from the point of view that there is an entrepreneurial education and support for the students enrolled in College of Business Administration at the Northern Boarder University.

Table 5. Rank of responses (Entrepreneurial education and support)

\begin{tabular}{|c|c|c|c|}
\hline \multicolumn{2}{|r|}{ Statements } & \multirow{2}{*}{$\begin{array}{c}\text { Frequency } \\
253\end{array}$} & \multirow{2}{*}{$\begin{array}{c}\text { percent } \% \\
95.1\end{array}$} \\
\hline 7 & $\begin{array}{l}\text { The university environment contributes to the enhancement of my personality toward independence } \\
\text { in the profession }\end{array}$ & & \\
\hline 3 & The courses provide students with the knowledge required to start a new company & 226 & 84.9 \\
\hline 5 & The university provides a strong network of new venture investors & 219 & 82.4 \\
\hline 2 & The courses foster the social and leadership skills needed by entrepreneurs & 215 & 80.8 \\
\hline \multirow[t]{2}{*}{1} & The creative atmosphere in my university inspires to develop ideas for new businesses & 177 & 66.5 \\
\hline & Overall & 1703 & 80 \\
\hline
\end{tabular}

As shown by Table 5, the statement stating that "the university environment contributes to the enhancement of my personality toward independence in the profession" is ranked as the highest level of agreement. The statement "the university environment contributes to the refinement of my personality toward risk trends" appears in the second rank. In the third rank comes a view related to the statement states: "the courses provide students with the 


\section{ENTREPRENEURSHIP AND SUSTAINABILITY ISSUES}

ISSN 2345-0282 (online) http://jssidoi.org/jesi/ 2020 Volume 8 Number 1 (September) http://doi.org/10.9770/jesi.2020.8.1(39)

knowledge required to start a new company." The fourth rank indicates "the university provides a strong network of new venture investors." The fifth rank is given to statement stating that the courses foster the social and leadership skills needed by entrepreneurs." The sixth rank is pointed to the view of "the university actively promotes the process of founding a new company." The seventh rank points to the view that "my university supports building multi-disciplinary student teams." The eighth rank indicates to the point view that "the creative atmosphere in my university inspires to develop ideas for new businesses." Overall, the respondents indicate that the university entrepreneurial education and support enhance the entrepreneurial intention (80\%).

\subsection{Hypothesis testing}

The objective of this study is to examine the degree of entrepreneurship education and support with the level of entrepreneurship intention in order to identify the extent to which the entrepreneurship education impacts the degree of the entrepreneurship intention. The dependent variable is the "entrepreneurial intention." The independent variable is the "entrepreneurial education and support" which consists of 8-items to measure the extent to which the "entrepreneurial education and support" prepares students to the entrepreneurship. A threepoint Likert Scale is used to measure the level of agreement towards whether the "entrepreneurial education and support" is deemed a good preparation for entrepreneurship. The Likert Scale is ranging from 1 (very accurate) indicating the highest agreement towards the contribution of the "entrepreneurial education and support" in preparing students for the entrepreneurship, to 3 (not at all accurate) indicating the lowest agreement towards the contribution of the "entrepreneurial education and support" in preparing students for the entrepreneurship. The "entrepreneurial education and support" is 8 items and one overall "entrepreneurial education and support category" (computed by averaging those 8 individual items). The 8 specific items of the "entrepreneurial education and support" and the overall "entrepreneurial education and support category" are tested for their reliability. The reliability means the accuracy which concern on stability, dependability and consistency of an instrument. In this study, the Cronbach's Alpha coefficient used is based on the average correlation of items within a test if the items are standardized. The reliability test shows the Cronbach's Alpha coefficients. The instruments are reasonably accepted for the purpose of reliability as the depicted in the following Table 6:

Table 6. Reliability test

\begin{tabular}{|c|l|c|}
\hline Items & The eight specific entrepreneurial education and support items & Alpha \\
\hline Item 1 & The creative atmosphere in my university inspires to develop ideas for new businesses & .785 \\
\hline Item 2 & The courses foster the social and leadership skills needed by entrepreneurs & .782 \\
\hline Item 3 & The courses provide students with the knowledge required to start a new company & .787 \\
\hline Item 4 & My university supports building multi-disciplinary student teams & .788 \\
\hline Item 5 & The university provides a strong network of new venture investors & .789 \\
\hline Item 6 & The university actively promotes the process of founding a new company & .781 \\
\hline Item 7 & The university environment contributes to the enhancement of my personality toward independence in the rofession & .849 \\
\hline Item 8 & The university environment contributes to the refinement of my personality toward risk trends & .845 \\
\hline Overall entrepreneurial education and support category & .824 \\
\hline \multicolumn{2}{|l}{} \\
\hline
\end{tabular}

Simple Regression (SR) was used to evaluate the level of association of entrepreneurial education and support with entrepreneurial intention. As shown by Table 4.13, the R2 is 0.042 which means that this model has explained $4.2 \%$ of the total variance in the entrepreneurial intention. 
Table 7. Model Summary

\begin{tabular}{|c|c|c|c|c|}
\hline Model & R & R Square & Adjusted R Square & Std. Error of the Estimate \\
\hline 1 & .206 & .042 & .039 & .562 \\
\hline
\end{tabular}

Table 8 depicts that the F-value for the model is statistically significant at the $1 \%$ level which means that the overall model can be interpreted.

Table 8. ANOVA Analysis

\begin{tabular}{|l|l|c|c|c|c|c|}
\hline \multirow{4}{*}{1} & Model & Sum of Squares & df & Mean Square & F & Sig. \\
\cline { 2 - 7 } & Regression & 3.683 & 1 & 3.683 & 11.649 & $.001^{\text {b }}$ \\
\cline { 2 - 7 } & Residual & 83.460 & 264 & .316 & & \\
\cline { 2 - 7 } & Total & 87.143 & 265 & & & \\
\hline
\end{tabular}

Table 9 illustrates the Simple Regression results. As shown by Table 9 that there is a significantly positive association between entrepreneurial education and support with entrepreneurial intention $(\beta=-.206, t=3.413, P$ $=.001$, one-tailed significance). Therefore, hypothesis $\mathrm{H} 1$ is accepted.

Table 9. Simple Regression $(\mathrm{n}=266)$

\begin{tabular}{|l|c|c|c|}
\hline \multicolumn{1}{|c|}{ Variables } & Coeff. & $t$ & $p$-value \\
\hline (Constant) & & 7.639 & .000 \\
\hline Test variable & & & \\
\hline EES & 0.206 & 3.413 & 0.001 \\
\hline
\end{tabular}

This result gives support to what Schulte (2004), Vicens and Grullón (2011), Goedhuys \& Sleuwaegen (2000), Ruiz et al. (2016), and Wells' (2014) documented that universities are playing and can play an important role in fostering entrepreneurship by equipping students with the right skills. They all agree that universities are hubs for innovation, creativity, leadership and critical thinking, which directly impact the wider society through their graduates. It is therefore imperative to ensure that students receive the right type of education to be able to make informed decisions afterwards. Entrepreneurship/entrepreneurial activity is a key way of assessing how any nation, economy, or sector is progressing, its quality, and how it may perform in future. They are essential for economic success, and any nation desiring a robust economic foundation should encourage the creation of small and medium-sized enterprises (SMEs).

\section{Conclusions and implications}

This study aims at testing the association of entrepreneurial education and support with entrepreneurial intention among students in College of Business Administration at the Northern Boarder University for the academic year 2019-2020. The results of this indicate that the students in College of Business Administration at Northern Boarder University have a high level of intention to be future businesspersons. This high degree of inclination gives a positive signal that the consequences on the economic growth would be great and positive (Sternberg \& Wennekers, 2005; Navarro et al., 2009; Acs \& Szerb, 2007; Audretsch \& Thurik, 2001; Marchesnay, 2011; 


\section{ENTREPRENEURSHIP AND SUSTAINABILITY ISSUES}

ISSN 2345-0282 (online) http://jssidoi.org/jesi/ 2020 Volume 8 Number 1 (September) http://doi.org/10.9770/jesi.2020.8.1(39)

Kasseeah. 2016; Ahmad \& Xavier, 2012). In addition, this entrepreneurial motivation would be the most powerful economic force in a manner that it contributes significantly to the unemployment problem (Ndofirepi, 2016; Ahmad \& Xavier, 2012). The differences in the entrepreneurial intention by demographic variables (gender, age, specialization, and study level) indicated that there are no significant differences exist in the entrepreneurial intention based on the respondents' different demographic information. The result of this study indicates that entrepreneurial education and support are associated with entrepreneurial intention. It gives indication that universities are playing and can play an important role in fostering entrepreneurship by equipping students with the right skills. They all agree that universities are hubs for innovation, creativity, leadership and critical thinking, which directly impact the wider society through their graduates. Thus, hypothesis H1 is accepted.

Results from this study have several implications to the theory. First, the results of the descriptive statistics show that the students in College of Business Administration at Northern Boarder University have a high level of intention to be future businesspersons. This high degree of inclination gives a positive signal that the consequences on the economic growth would be great and positive. In addition, this entrepreneurial motivation would be the most powerful economic force in a manner that it contributes significantly to the unemployment problem. In addition, the positive association between entrepreneurial education and support with entrepreneurial intention gives indication that universities are playing and can play an important role in fostering entrepreneurship by equipping students with the right skills. They all agree that universities are hubs for innovation, creativity, leadership and critical thinking, which directly impact the wider society through their graduates.

Therefore, the results of this study extends the previous studies in the entrepreneurship by adding a new empirical evidence on entrepreneurial intention, and entrepreneurial education and support in the setting of Saudi Arabia. Further, studies may replicate this study to enhance the external validity of the results. Finally, it would be of interesting to expand the research scope and models by using a more sophisticated technique such as structural equation modeling. This study also has several implications for practice. First, as there is a high degree of entrepreneurial intention among the students in College of Business Administration, it is considered a good quality and it is a part of the ambitious KSA 2030 Vision to achieve.

This study is limited to several limitations. First, the findings are limited to the specific sample. The sample is drawn partly from 266 students in College of Business Administration. Thus, generalizing the results may not give the same findings. Therefore, it is a worthwhile exercise to find out whether different colleges at the Northern Boarder University are a significant factor for entrepreneurial intention. The medical, engineering and humanitarian colleges could also include as a sample for the future study. Future research could also conduct a comparative analysis to examine whether there is a significant difference in the entrepreneurial intention among the students belong to different colleges. Second, this is a self-reported study in which the respondents were asked to rate a one-item indicating to their entrepreneurial intention. Future research may use different measurements to measure the entrepreneurial intention. As a result, different trends of results may be documented. Third, this study measures the perception of the students towards the entrepreneurial education and support using 8-items; hence, it may not be representative of actual entrepreneurial education and support, or different measures could be used. Future research may replicate the same study using a different measure of the entrepreneurial education and support. Finally, this study is conducted among the students in College of Business Administration at Norther Boarder University. Future studies may replicate this study in different Business Colleges in different universities in the KSA. 


\section{ENTREPRENEURSHIP AND SUSTAINABILITY ISSUES}

ISSN 2345-0282 (online) http://jssidoi.org/jesi/ 2020 Volume 8 Number 1 (September)

http://doi.org/10.9770/jesi.2020.8.1(39)

\section{References}

Abdieva, R. (2019). Gender differences, risk attitude and entrepreneurship in Kyrgyzstan. Economics and Business Letters, 8(1), 17-30. https://doi.org/10.17811/ebl.8.1.2019.17-30

Acs, Z.J., \& Szerb, L. (2007). Entrepreneurship, economic growth and public policy. Small Business Economics, 28 2-3, $109-122$. https://doi.org/10.1007/s11187-006-9012-3

Ajzen, I. (2002). Perceived behavioral control, self-efficacy, locus of control, and the theory of planned behavior. Journal of Applied Social Psychology, 32, 1-20. https://doi.org/10.1111/j.1559 1816.2002.tb00236.x

Ahmad, S.Z., \& Xavier, S.R. (2012). Entrepreneurial environments and growth: Evidence from Malaysia GEM data. Journal of Chinese

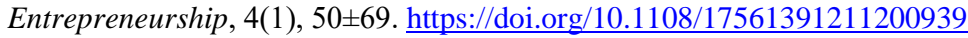

Alberti, F., Sciascia, S. \& Poli, A. (2004), Entrepreneurship education: notes on an ongoing debate, paper presented at 14th Annual IntEnt Conference, Naples, July 4-7.

Alessa, A. A. (2019). Entrepreneurial intention among saudi students: The role of personal attitude, subjective norms and perceived behavior control. SMART Journal of Business Management Studies, 15(1), 50-67.

Aneizi, I. O. (2009). Intention Toward Entrepreneurship: The Case of Libyan Master's Students in Universiti Utara Malaysia and Garyounis University (Master dissertation, Universiti Utara Malaysia).

Anne, G. P., \& Liisa, R. (2011). Changing the Teachers' thinking and action-Entrepreneurial Teacher Education. In ICSB World Conference Proceedings (p. 1). International Council for Small Business (ICSB).

Arias, E., Barba-Sánchez, V., Carrión, C., \& Casado, R. (2018). Enhancing Entrepreneurship Education in a Master's Degree in Computer Engineering: A Project-Based Learning Approach. Administrative Sciences, 8(4), 58. https://doi.org/10.3390/admsci8040058

Ariff, M., Husna, A., Bidin, Z., Sharif, Z., \& Ahmad, A. (2010). Predicting Entrepreneurship Intention among Malay University Accounting Students in Malaysia. Unitar e-Journal, 6(1).

Audretsch, D.B., \& Thurik, A.R. (2001). What's new about the new economy? Sources of growth in the managed and entrepreneurial economies. Industrial and Corporate Change, 10(1), 267-315. https://doi.org/10.1093/icc/10.1.267

Bae, J.T., Qian, S., Miao, C., \& Fiet, J.O. (2014). The relationship between Entrepreneurship Education and Entrepreneurial intentions: a Meta-Analytic Review. Entrepreneurship: Theory and Practice, 38(2), 217-245. https://doi.org/10.1111/etap.12095

Barba-Sánchez, V., \& Atienza-Sahuquillo, C. (2018). Entrepreneurial intention among engineering students: The role of entrepreneurship education. European Research on Management and Business Economics, 24(1), 53-61. http://dx.doi.org/10.1016/j.iedeen.2017.04.001

Bazan, C., Gaultois, H., Shaikh, A., Gillespie, K., Frederick, S., Amjad, A., ... \& Belal, N. (2020). Effect of the university on the social entrepreneurial intention of students. New England Journal of Entrepreneurship. Forthcoming. http://dx.doi.org/10.1108/NEJE$\underline{05-2019-0026}$

Busenitz, L.W., Plummer, L.A., Klotz, A.C., Shahzad, A., \& Rhoads, K. (2014). Entrepreneurship research (1985-2009) and the emergence of opportunities. Entrepreneurship Theory and Practice, 38(5), 981-1000. https://doi.org/10.1111/etap.12120

Charney, A., \& Libecap, G.D. (2000). The impact of entrepreneurship education: an evaluation of the Berger Entrepreneurship Program at the University of Arizona, 1985-1999. Available at SSRN 1262343.

Embi, N. A. C., Jaiyeoba, H. B., \& Yussof, S. A. (2019). The effects of students' entrepreneurial characteristics on their propensity to become entrepreneurs in Malaysia. Education+ Training, 61(7/8), 1020-1037. https://doi.org/10.1108/ET-11-2018-0229

Chienwattanasook, K., \& Jermsittiparsert, K. (2019). Impact of entrepreneur education on entrepreneurial self-employment: a study from Thailand. Polish Journal of Management Studies, 19(1), 106-116. https://doi.org/10.17512/pjms.2019.19.1.08 


\section{ENTREPRENEURSHIP AND SUSTAINABILITY ISSUES}

ISSN 2345-0282 (online) http://jssidoi.org/jesi/ 2020 Volume 8 Number 1 (September)

http://doi.org/10.9770/jesi.2020.8.1(39)

Cohen, J. (1992). A power primer. Psychological bulletin, 112(1), 155. https://doi.org/10.1037/0033-2909.112.1.155

Curry, M. (2012). Students 'perceptions of Entrepreneurship at a Historically Black University in Central Mississippi. (Doctoral dissertation, Mississippi State University). Retrieved from https://search.proquest.com/openview/6dfc6950e34618779d176650fa6f4b0a/1?pq-origsite=gscholar\&cbl=18750\&diss=y

Entrialgo, M., \& Iglesias, V. (2016). The moderating role of entrepreneurship education on the antecedents of entrepreneurial intention. International entrepreneurship and management journal, 12(4), 1209-1232. https://doi.org/10.1007/s11365-016-0389$\underline{4}$

Farrukh, M., Lee, J. W. C., \& Shahzad, I. A. (2019). Intrapreneurial behavior in higher education institutes of Pakistan. Journal of Applied Research in Higher Education, 11 (2), 273-294. https://doi.org/10.1108/JARHE-05-2018-0084

Fayolle, A. (2007). Handbook of research in entrepreneurship education. Contextual perspectives.

Fayolle, A., \& Gailly, B. (2015). The impact of entrepreneurship education on entrepreneurial attitudes and intention: hysteresis and persistence. Journal of Small Business Management, 53(1), 75-93.

Fayolle, A., Gailly, B., \& Lassas-Clerc, N. (2006). Assessing the impact of Entrepreneurship Education programmes: a new methodology. Journal of European Industrial Training, 30(9), 701-720. https://doi.org/10.1108/03090590610715022

Ferrandiz, J., Fidel, P., \& Conchado, A. (2018). Promoting entrepreneurial intention through a higher education program integrated in an entrepreneurship ecosystem. International Journal of Innovation Science, 10(1), 6-21. https://doi.org/10.1108/IJIS-09-2017-0089

Fitriati, R., \& Hermiati, T. (2011). Entrepreneurial Skills and Characteristics Analysis on the Graduates of the Department of Administrative Sciences, FISIP Universitas Indonesia. Bisnis \& Birokrasi Journal, 17(3).

Fulgence, K. (2015). Assessing the status of entrepreneurship education courses in higher learning institutions: The case of Tanzania education schools. Education+ Training, 57(2), 239-258. https://doi.org/10.1108/ET-05-2013-0063

Gelaidan, H. M., \& Abdullateef, A. O. (2017). Entrepreneurial intentions of business students in Malaysia. Journal of Small Business and Enterprise Development, 24(1), 54-67. https://doi.org/10.1108/JSBED-06-2016-0078

Gelard, P., \& Saleh, K.E. (2011). Impact of some contextual factors on entrepreneurial intention of university students. African Journal of Business Management, 5(26), 10707-10717. https://doi.org/10.5897/AJBM10.891

Gibb, A.A. (2002). In pursuit of a new 'enterprise' and 'entrepreneurship' paradigm for learning: creative destruction, new values, new ways of doing things and new combinations of knowledge. International Journal of Management Review, 4 (3), $233-269$. https://doi.org/10.1111/1468-2370.00086

Goedhuys, M., \& Sleuwaegen, L. (2000), Entrepreneurship and growth of entrepreneurial firms in Côte d'Ivoire. The Journal of Development Studies, 36 (3), 122-145. https://doi.org/10.1080/00220380008422631

Greene, P.G., Brush, C.G., Eisenman, E.J., Neck, H., \& Perkins, S. (2015). Entrepreneurship education: A global consideration from practice to policy around the world.

Henry, C., Hill, F., \& Leitch, C. (2005). Entrepreneurship education and training: can entrepreneurship be taught? Part I. Education+Training, 47 (2), 98-111. https://doi.org/10.1108/00400910510586524

Hoppe, M., Westerberg, M., \& Leffler, E. (2017). Educational approaches to entrepreneurship in higher education: A view from the Swedish horizon. Education+ training, 59(7/8), 751-767. https://doi.org/10.1108/ET-12-2016-0177

Kasseeah, H. (2016). Investigating the impact of entrepreneurship on economic development: a regional analysis. Journal of Small Business and Enterprise Development, 23(3), 896-916. https://doi.org/10.1108/JSBED-09-2015-0130

Kim, M., \& Park, M. J. (2019). Entrepreneurial education program motivations in shaping engineering students' entrepreneurial intention. Journal of Entrepreneurship in Emerging Economies, 11(3). 328-350. https://doi.org/10.1108/JEEE-08-2018-0082

Kolvereid, L. (1996). Organizational employment versus self-employment: reasons for career choice intentions. Entrepreneurship Theory and Practice, 20, 3, 23-31. https://doi.org/10.1177/104225879602000302 


\section{ENTREPRENEURSHIP AND SUSTAINABILITY ISSUES}

ISSN 2345-0282 (online) http://jssidoi.org/jesi/

2020 Volume 8 Number 1 (September)

http://doi.org/10.9770/jesi.2020.8.1(39)

Kuratko, D.F. (2004). Entrepreneurship education in the 21st century: From legitimization to leadership. In USASBE National Conference (Vol. 16).

Lopes, J., Teixeira, S. J., Ferreira, J. J., Silveira, P., Farinha, L., \& Lussuamo, J. (2020). University entrepreneurial intentions: mainland and insular regions-are they different?. Education+ Training, 62 (2), 81-99. https://doi.org/10.1108/ET-03-2019-0055

Luc, P. T. (2018). The relationship between perceived access to finance and social entrepreneurship intentions among university students in Vietnam. Journal of Asian Finance. Economics and Business, 5(1), 63-72. https://doi.org/10.13106/jafeb.2018.vol5.no1.63

Luthje, C. \& Franke, N. (2003). The making of an entrepreneur: testing a model of entrepreneurial intention among engineering students at MIT. R\&D Management, 33(2), 135-47. https://doi.org/10.1111/1467-9310.00288

Marchesnay, M. (2011). Fifty years of entrepreneurship and SME: a personal view. Journal of Small Business and Enterprise Development, 18(2), 352-365. https://doi.org/10.1108/14626001111127115

Martin, B.C., McNally, J.J., \& Kay, M.J. (2013). Examining the formation of Human Capital in Entrepreneurship: A Meta-Analysis of Entrepreneurship Education outcomes. Journal of Business Venturing, 28, 211-224. https://doi.org/10.1016/j.jbusvent.2012.03.002

Matlay, H. (2006). Entrepreneurship education: more questions than answers? Education p Training, 48 (5), 293-5. https://doi.org/10.1108/et.2006.00448eaa.001

Matlay, H. \& Carey, C. (2006). Entrepreneurship education in the UK: a critical perspective. Paper presented at the ISBE Conference, Cardiff, and November.

Matlay, H. \& Westhead, P. (2005). Virtual teams and the rise of e-entrepreneurship in Europe. International Small Business Journal, 12 (3), 279-302. https://doi.org/10.1177/0266242605052074

Miller, K. (2007). Teaching musicians to be entrepreneurs. Business Week, paras. 7-9\&16-18. Retrieved from http://www.Businessweek.com/smallbiz/content/mar2007/sb20070328_538120.htm

Mukwarami, S., Tengeh, R. K., \& Mukwarami, J. (2020). Responsible entrepreneurship: is there scope for its adoption by immigrantowned businesses in South African townships? Entrepreneurship and Sustainability Issues, 7(3), 1887-1901. https://doi.org/10.9770/jesi.2020.7.3(30)

Navarro, M.M., Iglesias, M.P., \& Torres, P.R. (2009). Curricular Profile of university graduates versus business demands. Education \& Training, 5(1), 56-69. https://doi.org/10.1108/00400910910931832

Ndofirepi, T.M. (2016). The impact of technological creativity and entrepreneurship education on the entrepreneurship intentions of students at particular tertiary institutions in Zimbabwe and South Africa (Doctoral dissertation, Bloemfontein: Central University of Technology, Free State).

Nabi, G., \& Holden, R. (2008). Graduate entrepreneurship: intentions, education and training. Education+ training, 50(7), 545-551. https://doi.org/10.1108/00400910810909018

Ooi, Y.K., Selvarajah, C., \& Meyer, D. (2011). Inclination towards entrepreneurship among university students: An empirical study of Malaysian university students. International Journal of Business and Social Science, 2(4), 206-220.

Otache, I. (2019a). Entrepreneurship education and undergraduate students' self-and paid-employment intentions. Education+ Training, 61(1), 46-64. https://doi.org/10.1108/ET-10-2017-0148

Otache, I. (2019b). Enhancing the effectiveness of entrepreneurship education: the role of entrepreneurial lecturers. Education+ Training, 61(7/8), 918-939. https://doi.org/10.1108/ET-06-2018-0127

Otache, I., Umar, K., Audu, Y., \& Onalo, U. (2019). The effects of entrepreneurship education on students' entrepreneurial intentions. Education+ Training. Forthcoming. https://doi.org/10.1108/ET-01-2019-0005

Parcell, J., \& Sykuta, M. (2005). Undergraduate perceptions of the need for an agricultural entrepreneurship curriculum. NACTA journal, 26-31. https://www.jstor.org/stable/43765921 


\section{ENTREPRENEURSHIP AND SUSTAINABILITY ISSUES}

ISSN 2345-0282 (online) http://jssidoi.org/jesi/ 2020 Volume 8 Number 1 (September)

http://doi.org/10.9770/jesi.2020.8.1(39)

Richardson, I. \& Hynes, B. (2008). Entrepreneurship education: towards an industry sector approach. Education p Training, 50(3), 188-99. https://doi.org/10.1108/00400910810873973

Ruiz, J., Soriano, D.R., \& Coduras, A. (2016). Challenges in measuring readiness for entrepreneurship. Management Decision, 54 (5), 1022-1046. https://doi.org/10.1108/MD-07-2014-0493

Ruskovaara, E., \& Pihkala, T. (2013). Teachers implementing entrepreneurship education: classroom practices. Education+ training, 55(2), 204-216. https://doi.org/10.1108/00400911311304832

Saji, B. S., \& Nair, A. R. (2018). Effectiveness of innovation and entrepreneurship education in UAE higher education. Academy of Strategic Management Journal, 17(4), 1-12.

Saudi Vision 2030. Retrieved March 27, 2017, from http://vision2030.gov.sa/en

Scholten, V., Kemp, R., \& Omta, O. (2004). Entrepreneurship for life: The entrepreneurial intention among academics in the life sciences. Paper prepared for European.

Schulte, P. (2004). The entrepreneurial university: a strategy for institutional development. Higher Education in Europe, 29(2), 187-191. https://doi.org/10.1080/0379772042000234811

Segal, G., Borgia, D., \& Schoenfeld, J. (2005). The motivation to become an entrepreneur. International Journal of Entrepreneurship Behavior \& Research, 11 (1), 42-57. https://doi.org/10.1108/13552550510580834

Shamsudin, S.F.F.B., Al Mamun, A., Nawi, N B.C., Nasir, N.A.B.M., \& Zakaria, M.N.B. (2017). Factors affecting entrepreneurial intention among the Malaysian university students. The Journal of Developing Areas, 51(4), 423-431. https://doi.org/10.1353/jda.2017.0111

Shamsudin, S.F.F.B., Al Mamun, A., Nawi, N.B.C., Nasir, N.A.B.M., \& Zakaria, M.N.B. (2016). Policies and practices for entrepreneurial education: The Malaysian experience. The Journal of developing areas, 50(5), 307-316. https://doi.org/10.1353/jda.2016.0053

Sternberg, R., \& Wennekers, S. (2005). Determinants and effects of new business creation using global entrepreneurship monitor data. Small Business Economics, 24 3), 193-214. https://doi.org/10.1007/s11187-005-1974-z

Teixeira, S. J., Casteleiro, C. M. L., Rodrigues, R. G., \& Guerra, M. D. (2018). Entrepreneurial intentions and entrepreneurship in European countries. International Journal of Innovation Science, 10 (1), 22-42. https://doi.org/10.1108/IJIS-07-2017-0062

Thomassen, M. L., Middleton, K. W., Ramsgaard, M. B., Neergaard, H., \& Warren, L. (2019). Conceptualizing context in entrepreneurship education: a literature review. International Journal of Entrepreneurial Behavior \& Research. Forthcoming https://doi.org/10.1108/IJEBR-04-2018-0258

Velilla, J., \& Ortega, R. (2020). Providing new products by innovative entrepreneurs in Europe. Economics and Business Letters, 9(2), 9096. https://doi.org/10.17811/ebl.9.2.2020.90-96

Vicens, L., \& Grullón, S. (2011). Innovation and Entrepreneurship: A Model Based on Entrepreneur Development. Retrieved from IADB Publications

Wells, S.J. (2014). Women entrepreneurs: Developing leadership for success. Routledge.

Wilson, K. (2008), Entrepreneurship Education in Europe, Entrepreneurship and Higher Education, European Foundation for Entrepreneurship Research, OECD, Paris, pp. 1-20. 


\section{ENTREPRENEURSHIP AND SUSTAINABILITY ISSUES}

ISSN 2345-0282 (online) http://jssidoi.org/jesi/ 2020 Volume 8 Number 1 (September)

http://doi.org/10.9770/jesi.2020.8.1(39)

Waddah OMER is an assistant professor of accounting in College of Business Administration at Northern Boarder University in Saudi Arabia. Omer's research intersts are auditing, corporate governance and related issues. Currently, Omer is the head of Administrative Sciences Department in the Community College, Northern Border University, Turaif, Saudi Arabia.

ORCID ID: https://orcid.org/0000-0001-9777-7497

Khaled ALJAAIDI is an associate professor of accounting in College of Business Administration at Prince Sattam bin Abdulaziz University. Aljaaidi is currently a Consultant in the Deanship of Development and Quality and the Director of Academic Development. Professionaly, Aljaaidi obtains the CMA and CPA certifications. His research interests are auditing, financial reporting, corporate governance and accounting education.

ORCID ID: https://orcid.org/0000-0002-0661-6813

Make your research more visible, join the Twitter account of ENTREPRENEURSHIP AND SUSTAINABILITY ISSUES:

@Entrepr69728810

Copyright (C) 2020 by author(s) and VsI Entrepreneurship and Sustainability Center

This work is licensed under the Creative Commons Attribution International License (CC BY).

http://creativecommons.org/licenses/by/4.0/

cC) (i) Open Access 